\title{
Pemilihan Titik Strategis untuk Pemasangan Reklame Produk Rokok di Kecamatan Cibinong Kabupaten Bogor menggunakan Metode Fuzzy Analytical Hierarchy Process (F-AHP)
}

\author{
Bobby Syawal Aprilian ${ }^{1}$, Lis Utari ${ }^{2}$ \\ ${ }^{1}$ Bobby Syawal Aprilian/Sistem Informasi/ \\ STIKOM Binaniaga Bogor \\ ${ }^{2}$ Lis Utari /TI/ Magister Komputer Teknik Informatika/ \\ STIKOM Binaniaga Bogor \\ Email: lis_utari@yahoo.co.id
}

\begin{abstract}
Organizing an advertisement for an area is governed by regional regulations. Bogor Regency Regional Regulation (BRRR) number 6 of 2004 concerning organizing advertisements; BRRR number 25 of 2011 concerning Advertising Taxes; BRRR number 7 of 2013 concerning the Sales Value of Advertising Tax Objects and Strategic Value of the location of the advertisement; explain about the installation area of the billboard. Cigarette product advertising is one of the regional income that has high value, but collides with Bogor Regency Regent's Regulations concerning Non-Cigarette Area Arrangement Article 7. The purpose of this study is to determine the Strategic Point for the Installation of Cigarette Product Advertisements in Cibinong District, Bogor Regency in accordance with the Regional Regulation The applicable KTR (Kawasan Tanpa Rokok) uses the Fuzzy Analytical Hierarchy Process (FAHP) Method. The number of criteria used in this study were 4 criteria, including location, location value, advertisement size and distance with public utilities. In addition, this study used 6 alternatives, namely Sukahati, Pabuaran, Pakansari, Major Oking, Cirimekar, and Nanggewer. The results of calculations using the FAHP method produce Major Oking ranked first with a value of 0.2110. Then the criteria and alternatives tested the consistency of the ratio with the results of Consistency Ratio $(C R)<0.1$ which stated the data was consistent.
\end{abstract}

Keywords: Fuzzy, Fuzzy Analytical Hierarchy Process

\begin{abstract}
ABSTRAK
Penyelenggaraan reklame suatu daerah diatur oleh peraturan daerah. Peraturan Daerah Kabupaten Bogor Nomor 6 Tahun 2004 tentang Penyelenggaraan Reklame; Peraturan Daerah Kabupaten Bogor Nomor 25 Tahun 2011 tentang Pajak Reklame; Peraturan Daerah Kabupaten Bogor Nomor 7 Tahun 2013 tentang Nilai Jual Objek Pajak Reklame dan Nilai Strategis Lokasi Reklame; menjelaskan tentang area pemasangan Reklame. Reklame Produk Rokok merupakan salah satu Penghasilan Daerah yang memiliki nilai tinggi, namun berbenturan dengan Peraturan Bupati Kabupaten Bogor tentang Pengaturan Kawasan Tanpa Rokok Pasal 7. Tujuan penelitian ini adalah untuk menentukan Titik Strategis Pemasangan Reklame Produk Rokok di Kecamatan Cibinong Kabupaten Bogor yang sesuai dengan Peraturan Perbup KTR yang berlaku menggunakan Metode Fuzzy Analytical Hierarchy Process (FAHP). Jumlah Kriteria yang digunakan pada penelitian
\end{abstract}


ini sebanyak 4 Kriteria, diantaranya yaitu Lokasi, Nilai Jual Lokasi, Ukuran Reklame dan Jarak dengan Utilitas Umum. Selain itu penelitian ini menggunakan 6 alternatif yaitu Sukahati, Pabuaran, Pakansari, Mayor Oking, Cirimekar, dan Nanggewer. Hasil perhitungan menggunakan Metode FAHP ini menghasilkan Mayor Oking di ranking pertama dengan nilai 0.2110. Kemudian Kriteria dan alternatif di uji konsistensi rasionya dengan hasil $C R<0.1$ yang menyatakan datanya sudah konsisten.

Kata kunci : Fuzzy, Fuzzy Analytical Hierarchy Process

\section{PENDAHULUAN}

\section{PEMILIHAN TITIK STRATEGIS UNTUK PEMASANGAN REKLAME PRODUK ROKOK DI KECAMATAN CIBINONG KABUPATEN BOGOR MENGGUNAKAN METODE FUZZY ANALYTICAL HIERARCHY PROCESS (F-AHP),}

Wilayah Kabupaten Bogor yang berada di antara wilayah DKI Jakarta dan wilayah-wilayah kabupaten/kota di Provinsi Jawa Barat merupakan salah satu area pemasangan reklame yang potensial terutama untuk jenis iklan Reklame Produk Tembakau/Rokok.

Reklame adalah benda, alat, perbuatan, atau media yang menurut bentuk, susunan dan corak ragamnya untuk tujuan komersil dan sosialisasi, dipergunakan untuk memperkenalkan, mengajurkan atau memujikan suatu barang, jasa atau orang ataupun untuk menarik perhatian umum kepada suatu barang, jasa atau orang yang ditempatkan atau yang dapat dilihat, dibaca, dan atau didengar dari suatu tempat oleh umum kecuali yang dilakukan oleh Pemerintah dan atau Pemerintah Daerah.

Penyelenggara Reklame adalah orang atau badan yang menyelenggarakan reklame, baik untuk dan atas namanya sendiri atau untuk dan atas nama pihak lain yang menjadi tanggungannya.

Promosi Produk Tembakau adalah kegiatan pengenalan atau penyebarluasan informasi tentang produk tembakau untuk menarik minat beli konsumen terhadap produk tembakau yang akan dan sedang diperdagangkan. Sponsor produk tembakau adalah segala bentuk kontribusi langsung atau tidak langsung, dalam bentuk dana atau lainnya, dalam berbagai kegiatan yang dilakukan oleh lembaga atau perorangan dengan tujuan mempengaruhi melalui promosi produk tembakau atau penggunaan produk tembakau.

Kawasan Tanpa Rokok, selanjutnya disingkat KTR adalah ruangan atau area yang dinyatakan dilarang untuk kegiatan merokok atau kegiatan mempengaruhi melalui promosi produk tembakau atau penggunaan produk tembakau seperti Fasilitas Pelayanan Kesehatan, Tempat Proses Belajar Mengajar, Tempat Anak Bermain, Tempat Ibadah, Angkutan Umum, Tempat Kerja, Tempat Umum dan Tempat Lain yang telah di tentukan oleh Pemerintah Daerah.

Potensi pemasangan reklame jenis produk rokok di wilayah Kabupaten Bogor antara lain dapat diketahui dari data berikut : 
Tabel Daftar Jumlah Reklame Jenis Rokok di Kabupaten Bogor

\begin{tabular}{|c|c|c|}
\hline JENIS & $\begin{array}{c}\text { JUMLAH } \\
\text { REKLAMIE }\end{array}$ & $\begin{array}{c}\text { JUMLAH } \\
\text { PAJAK }\end{array}$ \\
\hline Back & 79 & $805,684,921.88$ \\
\hline Banner & 1,267 & $53,755,000.00$ \\
\hline Bill & 442 & $1,256,148,750.00$ \\
\hline Front & 40 & $746,290,937.50$ \\
\hline Megatron & 2 & $801,562,500.00$ \\
\hline Poster & 5,140 & $388,800.00$ \\
\hline Spanduk & 986 & $57,171,406.25$ \\
\hline Umbu12 & 3,586 & $226,074,703.14$ \\
\hline $\begin{array}{c}\text { Grand } \\
\text { Total }\end{array}$ & $\mathbf{1 1 , 5 4 2}$ & $\mathbf{3 , 9 4 7 , 0 7 7 , 0 1 8 . 7 7}$ \\
\hline
\end{tabular}

Berdasarkan data yang menunjukan bahwa izin yang telah dikeluarkan mencapai 11.542 titik reklame Produk Rokok dengan total penerimaan pajak sebesar Rp.3.947.077.018,77 dari total penerimaan Pendapatan Asli Daerah Kabupaten Bogor dari sektor Pajak Reklame sebesar Rp. 18.453.489.345,11 dapat dikatakan bahwa Reklame Produk Rokok masih menjadi salah satu sumber penerimaan Pendapatan Asli Daerah yang terbesar.

Dengan banyaknya pemasangan reklame jenis rokok dan peraturan dari Pemerintah Daerah ini, maka muncul pula banyak permasalahan pada pemasangan reklame jenis rokok tersebut, diantaranya banyaknya para pihak penyelenggara reklame yang tidak mengetahui titik pemasangan reklame jenis rokok yang sesuai dengan peraturan yang ada dan sudah di tetapkan.

Untuk mengatasi masalah tersebut maka diperlukan suatu metode dalam pemilihan titik untuk pemasangan reklame jenis rokok yang sesuai dengan peraturan dan juga tentunya dengan peringkat nilai jual titik terbaik.Sehingga para penyelenggara reklame dapat memilih titik berdasarkan pembobotan kriteria yang sudah di tentukan oleh Pemerintah Daerah dengan nilai pajak yang sesuai dengan peringkatnya. Metode yang digunakan yaitu metode Fuzzy Analytical Hierarchy Process.

Dalam proses pengambilan keputusan yang melibatkan banyak kriteria, metode Fuzzy AHP dapat digunakan untuk menentukan bobot prioritas pada masing-masing kriteria yang menjadi dasar untuk analisa keputusan yang tepat.F-AHP merupakan gabungan metode AHP dengan pendekatan konsep fuzzy (Alwi dkk, 2013). F-AHP menutupi kelemahan yang terdapat pada AHP, yaitu permasalahan terhadap kriteria yang memiliki sifat subjektif lebih banyak.Ketidakpastian bilangan direpresentasikan dengan urutan skala.Untuk menentukan derajat keanggotaan pada FAHP, digunakan aturan fungsi dalam bentuk bilangan fuzzy segitiga atau Triangular Fuzzy 
Number (TFN) yang disusun berdasarkan himpunan linguistik.Jadi, bilangan pada tingkat intensitas kepentingan pada AHP ditransformasikan ke dalam himpunan skala TFN.

Dari hasil penelitian ini diharapkan dapat memberikan banyak manfaat baik bagi penyelenggara reklame dalam membantu menentukan titik pemasangan reklame jenis rokok yang sesuai dengan semua peraturan yang berlaku, dan juga untuk Pemerintah Daerah dalam penataan titik reklame dan tetap menjadi sumber Pendapatan Asli Daerah terbesar dari reklame jenis rokok ini.

\section{Rumusan Masalah}

Bidang Reklame adalah bidang yang mempunyai tugas membantu Kepala Dinas dalam melaksanakan pengelolaan reklame, pengawasan dan pengendalian reklame, dan penataan dan pendataan reklame dalam lingkup Kabupaten Bogor.

Bidang reklame sangat berperan penting dalam pemasangan segala jenis reklame di wilayah Kabupaten Bogor, semakin banyak reklame berizin yang terpasang maka semakin besar pula penerimaan Pendapatan Asli Daerah Kabupaten Bogor yang di terima setiap tahunnya.

Bidang reklame di beri kewenangan penuh untuk member izin ataupun menolak usulan titik pemasangan reklame yang diajukan oleh para penyelenggara reklame. Apabila titik yang diajukan sudah memenuhi persyaratan, mematuhi perundang-undangan dan estetika dalam pemasangannya, makan bidang reklame akan memberikan surat rekomendasi kepada penyelenggara reklame, agar nantinya bisa melanjutkan ke tahap pembayaran pajak dan proses perizinannya.

Saat ini sudah banyak sekali reklame produk rokok yang terpasang di wilayah Kabupaten Bogor khususnya di Kecamatan Cibinong antara lain dapat diketahui dari data berikut :

Tabel Data Reklame Produk Rokok di Kecamatan Cibinong

\begin{tabular}{|c|c|c|c|c|c|c|c|c|}
\hline NAMA PEMOHON & NASKAH REKLAME & LOKASI PEMASANGAN & JENIS & PANJANG & LEBAR & MUKA & LUAS & NILAI PAJAK \\
\hline $\begin{array}{l}\text { ABDUL BAHAR } \\
\text { LESTALUHU }\end{array}$ & $\begin{array}{c}\text { Produk Rokok Gudang } \\
\text { Garam }\end{array}$ & Wilayah Kec. Cibinong & Banner & 1.00 & 2.00 & 1 & 2.00 & $2,475,000.00$ \\
\hline $\begin{array}{l}\mathrm{CV} . \text { WAHYU/R. } \\
\text { WAHYU } \\
\text { FABRIANSYAH }\end{array}$ & $\begin{array}{l}\text { Produk Rokok } \\
\text { Sampoerna }\end{array}$ & $\begin{array}{l}\text { Toko Rizki } 05 \text { Jl. Raya Sukahati } \\
\text { Kec. Cibinong }\end{array}$ & Bill & 2.00 & 1.00 & 2 & 4.00 & $2,025,000.00$ \\
\hline $\begin{array}{c}\mathrm{CV} . \text { WAHYU/R. } \\
\text { WAHYU } \\
\text { FABRIANSYAH }\end{array}$ & $\begin{array}{l}\text { Produk Rokok } \\
\text { Sampoerna }\end{array}$ & $\begin{array}{l}\text { Toko Ali Sukahati Jl. Raya } \\
\text { Pemda Sukahati Kec. Cibinong }\end{array}$ & Bill & 2.00 & 1.00 & 2 & 4.00 & $2,025,000.00$ \\
\hline $\begin{array}{l}\text { PT. GEMA KARYA } \\
\text { BUANA }\end{array}$ & Produk Sampoerna & $\begin{array}{l}\text { Jl. Raya Jakarta Bogor Kel. } \\
\text { Pabuaran Kec. Cibinong }\end{array}$ & Backlight & 4.00 & 6.00 & 1 & 24.00 & $16,200,000.00$ \\
\hline $\begin{array}{l}\text { ANEKA KARYA } \\
\text { ADVERTISING, PT }\end{array}$ & Produk Djarum & $\begin{array}{l}\text { Jl. Raya Bogor Pertigaan Pemda } \\
\text { Kec. Cibinong }\end{array}$ & Backlight & 2.00 & 4.00 & 1 & 8.00 & $5,400,000.00$ \\
\hline
\end{tabular}

Untuk pemasangan reklame produk rokok, tidak di perbolehkan di pasang di jalan protokol, namun hingga saat ini belum ada penentuan ruas jalan protokol di wilayah Kecamatan Cibinong. Untuk ukuran reklame produk rokok, maksimal memiliki luas $72 \mathrm{~m}^{2}$ dan tentunya berjarak $100 \mathrm{~m}$ dari utilitas umum. Namun, masih banyak reklame yang di pasang di radius kurang dari 100m dari utilitas umum. Hal ini yang membuat penulis tertarik untuk menentukan titik strategis pemasangan 
reklame produk rokok di Kecamatan Cibinong Kabupaten Bogor. Agar nantinya tidak ada reklame yang harus di tertibkan oleh pemerintah daerah, yang menimbulkan kerugian kepada para penyelenggara reklame dan tanpa mengurangi minat para penyelenggara reklame untuk mengiklankan produk rokok yang masih menjadi penghasil Pendapatan Asli Daerah tertinggi.

Dari uraian data di atas dapat diidentifikasi masalah sebagai berikut

1.Belum diketahui bobot kriteria yang digunakan untuk penempatan reklame produk rokok di Kecamatan Cibinong

2.Belum tepat pemilihan titik pemasangan reklame produk rokok di

\section{Maksud dan Tujuan Penelitian}

Maksud dari penelitian ini adalah untuk mendapatkan cara penentuan titik pemasangan titik reklame produk rokok di Kecamatan Cibinong Kabupaten Bogor menggunakan metode Fuzzy Analytical Hierarchy Process sebagai metode pengambilan keputusan.

Adapun tujuan penelitian ini adalah :

1. Untuk mengetahui bobot kriteria yang di gunakan untuk penempatan reklame produk rokok di Kecamatan Cibinong.

2. Untuk menentukan titik yang tepat untuk pemasangan reklame produk rokok di Kecamatan Cibinong.

\section{Tinjauan Pustaka}

Penelitian yang menjadi acuan penulisan adalah penelitian yang dilakukan oleh Wahyudi Setiawan,Reny Pujiastutik (2015) pada Manajemen Informatika Universitas Trunojoyo madura yang berjudul Penerapan Metode Fuzzy Analytical Hierarchy Process untuk Pemilihan Supplier Batik Madura. Penelitian ini membahas tentang proses pemilihan supplier terbaik bagi perusahaan berdasarkan 13 kriteria diantaranya yaitu cara pembayaran, harga, diskon, jumlah pengiriman, kecepatan tanggap, komunikasi, informasi produk, layanan complain, kualitas produk, tingkat kecacatan, biaya transportasi dan jenis transportasi. untuk membantu perusahaan menentukan supplier dengan biaya yang minimal dan meningkatkan daya saing perusahaan. Oleh karena itu digunakan Fuzzy Analytical Hierarchy Process (F-AHP).Metode ini dipilih karena mampu menentukan perankingan terbaik dengan alternative yang ada.Disini alternative yang dimaksud adalah calon supplier berdasarkan setiap kriteria yang telah di tentukan.Bobot yang diberikan pada setiap kriteria mempengaruhi hasil akhir penentuan calon supplier batik Madura terbaik.Perubahan nilai bobot kriteria mempengaruhi hasil akhir perhitungan.

Dari contoh penelitian di atas, maka peneliti memilih Fuzzy Analythical Hierarchy Process untuk diterapkan pada Penerapan Metode Fuzzy Analythical Hierarchy Process Pemilihan Titik Strategis Pemasangan Reklame Produk Rokok di Kecamatan Cibinong Kabupaten Bogor. 
Penelitian ini menggunakan metode Fuzzy Analythical Hierarchy Process karena peneliti melakukan pembobotan kriteria titik strategis pemasangan Reklame Produk Rokok menggunakan Perangkingan berdasarkan 4 Kriteria yang telah ditentukan yaitu Lokasi, Nilai Jual Lokasi, Ukuran Reklame dan Jarak dengan Utilitas Umum yang telah di tetapkan pada undang-undang peraturan daerah tentang kawasan tanpa rokok (KTR).

Hasil dari pengumpulan data potensi reklame tahun 2016 yang akan menjadi dasar pengambilan keputusan untuk menentukan titik strategis pemasangan reklame produk rokok di Kabupaten Bogor.

\section{METODE}

\section{ANALYTICAL HIERARCHY PROCESS (AHP)}

\section{Definisi Analytical Hierarchy Process (AHP)}

Kusrini (2007). Konsep dan aplikasi system pendukung keputusan, menyatakan bahwa proses pengambilan keputusan adalah memilih suatu alternatif. Analytical Hierarchy Process (AHP) adalah metode keputusan multikriteria untuk pemecahan masalah yang kompleks. Peralatan utama AHP adalah sebuah hierarki fungsional dengan input utamanya persepsi manusia.

Analytical Hierarchy Process (AHP) diperkenalkan oleh DR. Thomas L. Saaty pada tahun 1970. Pada saat itu, AHP merupakan salah satu metode yang dapat digunakan dalam system pengambilan keputusan dengan memperhatikan faktor-faktor persepsi, preferensi, pengalaman dan

\section{Kegunaan Analytical Hierarchy Process (AHP)}

AHP memberikan kesempatan bagi seorang untuk membangun gagasan-gagasan dan mendefinisikan persoalan dengan cara membuat asumsi masing-masing sehingga mempermudah pemecahan yang diinginkan. Beberapa kegunaan Analytical Hierarchy Process (AHP) diantaranya:

a. Untuk memecahkan permasalahan yang kompleks secara kuantitatif.

b. Untuk mengalokasikan sumber daya di antara berbagai macam alternatif baik yang sudah ada maupun yang baru.

c. Untuk memproyeksi dan memberikan jaminan terhadap resiko ketidak pastian.

\section{Logika FUZZY}

Kata fuzzy merupakan kata sifat yang berarti kabur atau tidak jelas. Logika fuzzy digunakan sebagai suatu cara untuk memetakan permasalahan dari input menuju ke output yang diharapkan (Kusumadewi, 2013:1). Logika fuzzy menggunakan derajat keanggotaan dari sebuah nilai yang kemudian digunakan untuk menentukan hasil yang ingin dihasilkan berdasarkan atas spesifikasi yang telah ditentukan. 


\section{a. Himpunan Fuzzy}

Teori yang terkait dengan himpunan yang nilai derajat keanggotaannya berubah secara bertahap adalah fuzzy set theory (teori himpunan fuzzy), yang diperkenalkan oleh Zadeh (1965). Himpunan fuzzy didasarkan pada gagasan untuk memperluas jangkauan fungsi karakteristik sehingga fungsi tersebut akan mencakup bilangan real pada interval. Himpunan fuzzy digunakan untuk mengantisipasi nilai-nilai yang bersifat tidak pasti. Pada himpunan tegas (crisp), nilai keanggotaan suatu item $x$ dalam suatu himpunan $A$, yang sering ditulis dengan $\mu \mathrm{A}(\mathrm{x})$, memiliki dua kemungkinan, yaitu satu (1), yang berarti bahwa suatu item tidak menjadi anggota dalam suatu himpunan atau nol (0), yang berarti bahwa suatu item tidak menjadi anggota dalam suatu himpunan. (Kusumadewi,2013:3).

Pada himpunan fuzzy nilai keanggotaan terletak pada rentang 0 sampa 1, yang berarti himpunan fuzzy dapat mewakili interpretasi tiap nilai berdasarkan pendapat atau keputusan dan probabilitasnya, nilai 0 menunjukkan salah dan nilai 1 menunjukkan benar dan masih ada nilainilai yang terletak antara benar dan salah. Dengan kata lain nilai kebenaran suatu item tidak hanya benar atau salah.

Himpunan fuzzy memiliki dua atribut, yaitu:

1. Linguistik, yaitu penamaan suatu grup yang mewakili suatu keadaan atau kondisi tertentu dengan menggunakan bahasa alami, seperti: muda, parobaya, tua

2. Numeris, yaitu suatu nilai (angka) yang menunjukkan ukuran dari suatu variabel seperti: 40,25,50 dan sebagainya.

\section{b. Fungsi Keangotaan}

Fungsi keanggotaan (membership function) adalah suatu kurva yang menunjukkan pe Fungsi keanggotaan (membership function) adalah suatu kurva yang memiliki pemetaan titik-titik input data kedalam nilai keanggotaannya (derajat keanggotaan) yang memiliki interval) antara nol sampai satu. Salah satu cara yang dapat digunakan untuk mendapatkan nilai keanggotaan adalah dengan melalui pendekatan fungsi (Kusumadewi, 2013:8).

Beberapa fungsi yang bisa digunakan, diantaranya adalah:

\section{Representasi Linear}

Pada representasi linear, pemetaan input ke derajat keanggotaannya digambarkan sebagai suatu garis lurus. Bentuk ini paling sederhana dan menjadi pilihan yang baik untuk mendekati suatu konsep yang kurang jelas. Ada 2 (dua) representasi fuzzy linear:

Representasi linear naik: kenaikan himpunan dimulai pada nilai domain yang memiliki derajat keanggotaan nol (0) bergerak ke kanan menuju kenilai domain yang memiliki derajat keanggotaan lebih tinggi. 
Representasi linear turun: merupakan kebalikan yang pertama. Garis lurus dimulai dari nilai domain dengan derajat keanggotaan tertinggi pada sisi kiri, kemudian bergerak menurun ke nilai domain yang memiliki derajat keanggotaan lebih rendah.

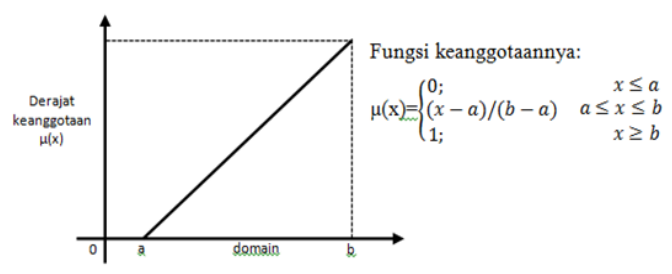

Gambar Representasi Linear naik

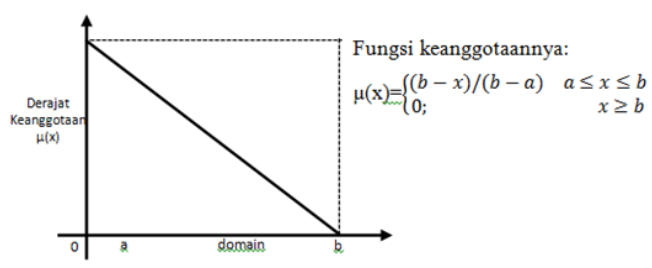

Gambar Representasi linear

turun

Representasi Kurva Segitiga \& Kurva Trapesium: merupakan gabungan dua garis (linear).

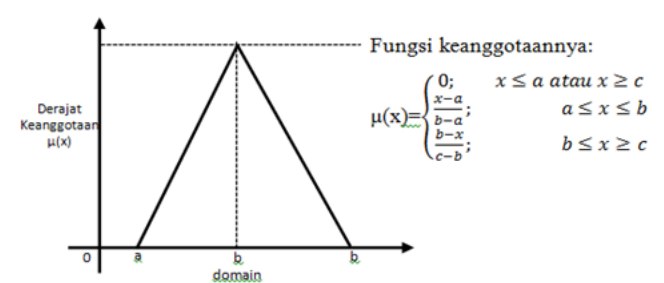

Gambar Representasi kurva segitiga

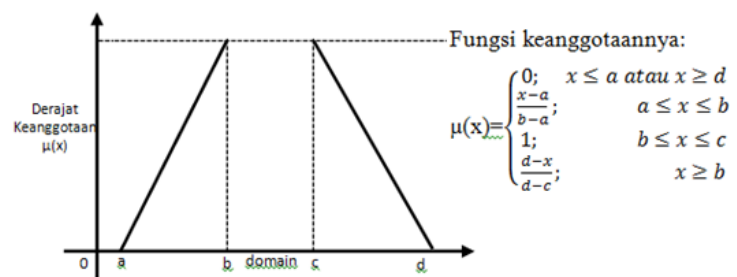

Gambar Representasi kurva trapezium

\section{Konsep Penerapan Fuzzy Analythic Hierarchy Process (FAHP)}

Model Analytical Hierarchy Process (AHP) pertama yang dikembagkan oleh Thomas L. Saaty merupakan AHP dengan pembobotan additive, disebut additive karena operasi aritmatika untuk mendapatkan bobot totalnya adalah penjumlahan.

Didalam penerapan AHP untuk pengambilan keputusan dengan kriteria yang bersifat subjektif, seringkali seorang pengambil keputusan dihadapkan pada suatu masalah yang sulit dalam menentukan bobot setiap kriteria. Untuk menangani kelemahan AHP ini diperlukan suatu metode yang lebih memperhatikan keberadaan kriteria-kriteria yang bersifat subjektif tersebut. Salah satu metode pendekatan yang dipakai dalam pengembangan AHP ini adalah model FUZZY AHP dengan pembobotan non additive.

Prosedur perhitungan Fuzzy AHP non additive terdiri dari tiga langkah yaitu :

a. Penilaian alternatif terhadap setiap kriteria,

b. Pembobotan kriteria, dan

c. Perhitungan nilai akhir. 


\section{HASIL DAN PEMBAHASAN}

\section{Hasil Penelitian (Menentukan Kriteria dan Alternatif)}

Dalam menentukan titik strategis pemasangan reklame produk rokok di Kecamatan Cibinong Kabupaten Bogor ada beberapa variabel yang terlebih dahulu di tentukan. Kriteria yang diterapkan dalam penelitian ini terdiri dari 4 (empat) variabel, yaitu: Lokasi, Nilai Jual Lokasi, Ukuran Reklame, Jarak dengan Utilitas Umum.

Berdasarkan data yang telah tersedia di Bidang Reklame pada Dinas Perumahan Kawasan Permukiman dan Pertanahan Kabupaten Bogor, terdapat 6 alternatif yang di gunakan dalam menentukan titik strategis pemasangan reklame produk rokok di Kecamatan Cibinong Kabupaten Bogor, antara lain sebagai berikut : Sukahati, Pabuaran, Pakansari, Mayor Oking, Cirimekar, Nanggewer.

Hasil dari penelitian yang dilakukan adalah diperolehnya Rangking lokasi /Titik Strategis Pemasangan Reklame Produk Rokok di Kecamatan Cibinong Kabupaten Bogor.

Tabel. Hasil Perangkingan Titik Strategis

\begin{tabular}{|c|c|c|}
\hline Ranking & Alternatif & Bobot Akhir \\
\hline 1 & Mayor Oking & 0.2110 \\
\hline 2 & Nanggewer & 0.1713 \\
\hline 3 & Sukahati & 0.1593 \\
\hline 4 & Pabuaran & 0.1528 \\
\hline 5 & Pakansari & 0.1528 \\
\hline 6 & Cirimekar & 0.1528 \\
\hline \multicolumn{2}{|c|}{ Total } & 1.0000 \\
\hline
\end{tabular}

\section{PEMBAHASAN}

\section{a. Pembentukan Struktur Hierarki Kriteria dan Sub Kriteria}

Kriteria dan alternatif yang telah di tentukan kemudian akan dibentuk sesuai dengan struktur hierarki pada metode Fuzzy AHP. Adapun Struktur Hierarkhi Fuzzy AHP yang digunakan dapat dilihat pada Gambar berikut:

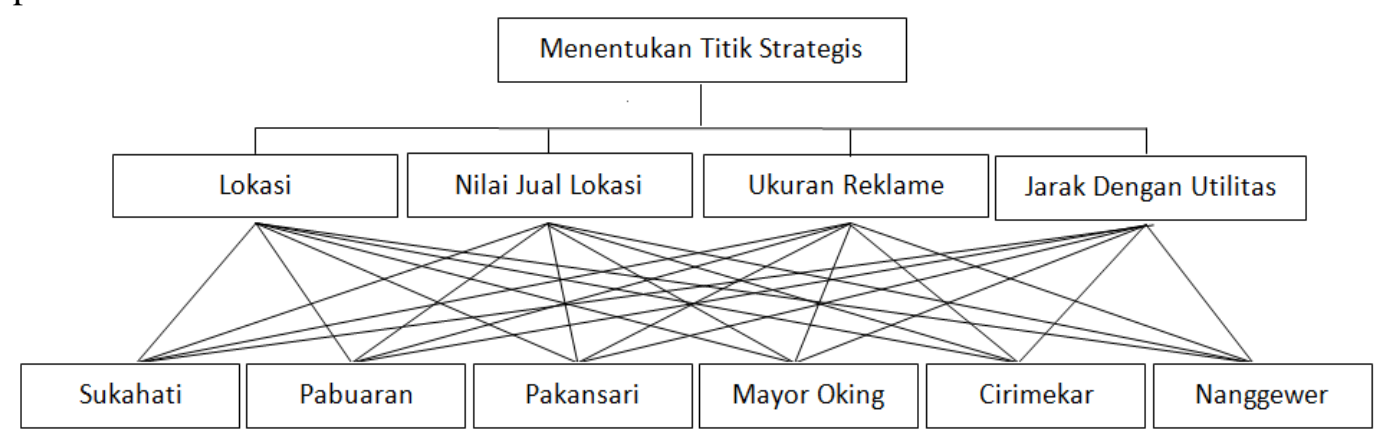

Gambar Struktur Hierarkhi Penelitian 
Setelah diperoleh Goal, Kriteria dan Alternatif yang akan digunakan dalam penelitian untuk menentukan bobot dan indeks alternative gabungan, maka langkah selanjutnya adalah mendisain Kuesioner yang akan diberikan kepada responden dalam rangka meminta pendapat pada para ahli Penyelenggaraan Reklame.

\section{b. Penentuan bobot Kriteria dan Alternatif}

Proses pertama yang harus dilakukan dalam penentuan bobot akriteria dan alternative ialah melakukan perbandingan antara kriteria dengan menggunakan skala linguistic.

Tabel Skala Saaty terhadap Triangular Fuzzy Number

\begin{tabular}{|c|c|}
\hline Nilai & Nilai Skala Perbandingan \\
\hline 1 & Sama Penting (Equal) \\
\hline 3 & Sedikit lebih penting (Moderate) \\
\hline 5 & Lebih Penting (Strong) \\
\hline 7 & Sangat lebih penting (Very Strong) \\
\hline 9 & Mutlak lebih penting sekali (Extreme) \\
\hline $2,4,6,8$ & Nilai Diantara dua pilihan yang berdekatan \\
\hline
\end{tabular}

Dari nilai skala perbandingan tersebut, kemudian diaplikasikan dalam kuisioner yang di sebarkan kepada para Penyelenggara Reklame. Nilai perbandingan untuk setiap Kriteria dan Alternatif kemudian dibuatkan matriks perbandingan berpasangan untuk kriteria dan alternatif dengan hasil perbandingan pada Tabel-tabel dibawah ini:

Tabel Contoh Quisioner data kriteria

\begin{tabular}{|l|l|l|l|l|}
\hline & Lokasi & Nilai & Ukuran & Jarak \\
\hline Lokasi & 1 & $\ldots$ & $\ldots$ & $\cdots$ \\
\hline Nilai & & 1 & $\cdots$ & $\cdots$ \\
\hline Ukuran & & & 1 & $\cdots$ \\
\hline Jarak & & & & 1 \\
\hline
\end{tabular}

Tabel Contoh Quisioner data Alternatif terhadap Kriteria (Lokasi, Nilai Jual Lokasi, Ukuran Reklame, Jarak dengan Utilitas Umum) 


\begin{tabular}{|l|l|l|l|l|l|l|}
\hline & Sukahati & Pabuaran & Pakansari & Mayor Oking & Cirimekar & Nanggewer \\
\hline Sukahati & 1 & & & & & \\
\hline Pabuaran & & & & & & \\
\hline Pakansari & & & 1 & & & \\
\hline Mayor Oking & & & & 1 & & \\
\hline Cirimekar & & & & & 1 & \\
\hline Nanggewer & & & & & & 1 \\
\hline
\end{tabular}

\section{c. Uji Konsistensi Kriteria dan Alternatif (AHP)}

Setelah Quisioner di isi oleh para penyelenggara reklame dimana sebagai responden, maka hasil pengisian tersebut direkap (lampiran), kemudian di ambil nilai rata-rata dari seluruh data quisioner tersebut.

Setelah diperoleh nilai rata-rata dari data questioner, selanjutnya disusun kedalam matriks perbandingan berpasangan dan dilakukan perhitungan vector prioritas (eigen vector) dari matriks perbandingan berpasangan pada Tabel-tabel dibawah ini:

Tabel Rekap Data Kriteria

\begin{tabular}{|l|l|l|l|l|}
\hline & Lokasi & Nilai & Ukuran & Jarak \\
\hline Lokasi & 1.0000 & 0.9751 & 1.5959 & 1.3040 \\
\hline Nilai & 1.0255 & 1.0000 & 2.5418 & 1.6311 \\
\hline Ukuran & 0.6266 & 0.3934 & 1.0000 & 1.5060 \\
\hline Jarak & 0.7669 & 0.6131 & 0.6640 & 1.0000 \\
\hline Jumlah & 3.4190 & 2.9816 & 5.8017 & 5.4411 \\
\hline
\end{tabular}

Tabel Rekap data Kriteria adalah tabel hasil rekap data Quisioner yang Kemudian di jumlahkan setiap barisnya, sedangkan tabel-tabel dibawah ini adalah data hasil rekap quisioner alternative terhadap setiap kriteria.

Tabel Rekap data Alternatif Terhadap Kriteria Lokasi

\begin{tabular}{|c|c|c|c|c|c|c|}
\hline & Sukahati & Pabuaran & Pakansari & Mayor Oking & Cirimekar & Nanggewer \\
\hline Sukahati & 1.0000 & 1.9846 & 1.5803 & 1.0221 & 1.5140 & 1.6265 \\
\hline Pabuaran & 0.5039 & 1.0000 & 0.9719 & 0.8540 & 0.9936 & 0.8206 \\
\hline Pakansari & 0.6328 & 1.0289 & 1.0000 & 0.9734 & 1.0078 & 0.9300 \\
\hline Mayor Oking & 0.9784 & 1.1710 & 1.0273 & 1.0000 & 2.5226 & 2.2397 \\
\hline Cirimekar & 0.6605 & 1.0064 & 0.9923 & 0.3964 & 1.0000 & 0.8596 \\
\hline Nanggewer & 0.6148 & 1.2186 & 1.0753 & 0.4465 & 1.1633 & 1.0000 \\
\hline
\end{tabular}


Tabel Rekap data Alternatif Terhadap Kriteria Nilai

\begin{tabular}{|c|c|c|c|c|c|c|}
\hline & Sukahati & Pabuaran & Pakansari & Mayor Oking & Cirimekar & Nanggewer \\
\hline Sukahati & 1.0000 & 1.0904 & 0.9256 & 0.9207 & 0.9075 & 0.9143 \\
\hline Pabuaran & 0.9171 & 1.0000 & 0.9333 & 0.9058 & 0.9945 & 0.8613 \\
\hline Pakansari & 1.0803 & 1.0715 & 1.0000 & 0.9141 & 1.0494 & 0.9645 \\
\hline Mayor Oking & 1.0861 & 1.1040 & 1.0939 & 1.0000 & 3.2331 & 1.5991 \\
\hline Cirimekar & 1.1020 & 1.0056 & 0.9529 & 0.3093 & 1.0000 & 0.9065 \\
\hline Nanggewer & 1.0938 & 1.1610 & 1.0368 & 0.6254 & 1.1032 & 1.0000 \\
\hline
\end{tabular}

Tabel Rekap data Alternatif Terhadap Kriteria Ukuran

\begin{tabular}{|c|c|c|c|c|c|c|}
\hline & Sukahati & Pabuaran & Pakansari & Mayor Oking & Cirimekar & Nanggewer \\
\hline Sukahati & 1.0000 & 0.9924 & 0.9266 & 0.4910 & 0.9241 & 0.6554 \\
\hline Pabuaran & 1.0077 & 1.0000 & 1.0004 & 0.9259 & 0.8932 & 0.9296 \\
\hline Pakansari & 1.0793 & 0.9996 & 1.0000 & 0.9063 & 0.9860 & 0.9281 \\
\hline Mayor Oking & 2.0365 & 1.0800 & 1.1034 & 1.0000 & 2.5177 & 0.9255 \\
\hline Cirimekar & 1.0821 & 1.1195 & 1.0142 & 0.3972 & 1.0000 & 0.9113 \\
\hline Nanggewer & 1.5257 & 1.0758 & 1.0775 & 1.0805 & 1.0973 & 1.0000 \\
\hline
\end{tabular}

Tabel Rekap data Alternatif Terhadap Kriteria Jarak

\begin{tabular}{|c|c|c|c|c|c|c|}
\hline & Sukahati & Pabuaran & Pakansari & Mayor Oking & Cirimekar & Nanggewer \\
\hline Sukahati & 1.0000 & 1.0283 & 0.9352 & 0.8752 & 0.9407 & 0.9033 \\
\hline Pabuaran & 0.9725 & 1.0000 & 0.9366 & 0.8989 & 0.9351 & 0.6207 \\
\hline Pakansari & 1.0693 & 1.0677 & 1.0000 & 0.9134 & 1.0010 & 0.9308 \\
\hline Mayor Oking & 1.1426 & 1.1125 & 1.0948 & 1.0000 & 0.8947 & 2.0520 \\
\hline Cirimekar & 1.0631 & 1.0694 & 0.9990 & 1.1176 & 1.0000 & 0.3413 \\
\hline Nanggewer & 1.1071 & 1.6110 & 1.0743 & 0.4873 & 2.9297 & 1.0000 \\
\hline
\end{tabular}

Jumlah perbandingan berpasangan adalah $\mathrm{n}(\mathrm{n}-1) / 2$ karena saling berbalikan dan diagonalnya selalu bernilai satu. Kepentingan relative dari setiap faktor dari setiap baris dari matriks dapat dinyatakan sebagai bobot relatif yang dinormalkan. Bobot ini merupakan suatu nilai relatif untuk masing-masing faktor pada setiap kolom dengan membandingkan masing-masing nilai skala dengan jumlah kolomnya. Sebagai contoh bobot relative yang dinormalkan dari kriteria lokasi terhadap lokasi dalam tabel 4.8 adalah $1 / 3.4190=0.2925$, sedangkan bobot relative yang dinormalkan dari kriteria nilai terhadap lokasi adalah $1.0255 / 3.4190=0.3000$ dan seterusnya.

Kemudian di buat kedalam normalisasi matriks yang didapatkan dari nilai perbandingan berpasangan setiap kriteria dibagi jumlah kolom, seperti pada tabel dibawah ini: 
Tabel Tabel Normalisasi Kriteria

\begin{tabular}{|c|c|c|c|c|c|}
\hline & Lokasi & Nilai & Ukuran & Jarak & Rata/Vp \\
\hline Lokasi & 0.2925 & 0.3270 & 0.2751 & 0.2397 & 0.2836 \\
\hline Nilai & 0.3000 & 0.3354 & 0.4381 & 0.2998 & 0.3433 \\
\hline Ukuran & 0.1833 & 0.1319 & 0.1724 & 0.2768 & 0.1911 \\
\hline Jarak & 0.2243 & 0.2056 & 0.1145 & 0.1838 & 0.1820 \\
\hline
\end{tabular}

Eigen vector utama merupakan bobot rasio dari masing-masing faktor. Pada tabel di atas responden menilai kriteria Nilai Jual Lokasi sebagai faktor utamanya. selanjutnya untuk mendapatkan nilai $\lambda$ max digunakan rumus dan persamaan sebagai berikut :

$$
\mathbf{C l}=\frac{(\lambda \max -n)}{(n-1)}
$$

Dimana: $\mathrm{Cl}=$ Rasio penyimpangan (deviasi) konsistensi (Konsistensi Indeks)

$$
\begin{aligned}
\lambda \max & =\text { Nilai eigen terbesar dari matriks berordo } n \\
\mathrm{n} & =\text { banyaknya kriteria }
\end{aligned}
$$

Batas ketidakkonsistenan (inconsistency) ditentukan dengan menggunakan Rasio Konsistensi $(C R)$, yaitu perbandingan Konsistensi Indeks $(\mathrm{Cl})$ dengan nilai random indeks $(R I)$ yang diperlihatkan pada dibawah dengan nilai bergantung pada n. Rasio konsistensi dirumuskan sebagai berikut :

$$
\mathrm{CR}=\frac{C I}{R I}
$$
Dimana $:$ CR $=$ Konsistensi Rasio
RI $\quad=$ Random Indeks

Tabel Normalisasi Alternatif Terhadap Kriteria Lokasi

\begin{tabular}{|c|c|c|c|c|c|c|c|}
\hline & Sukahati & Pabuaran & Pakansari & Mayor Oking & Cirimekar & Nanggewer & Rata / Vp \\
\hline Sukahati & 0.2278 & 0.2678 & 0.2377 & 0.2178 & 0.1846 & 0.2176 & 0.2256 \\
\hline Pabuaran & 0.1148 & 0.1350 & 0.1462 & 0.1820 & 0.1212 & 0.1098 & 0.1348 \\
\hline Pakansari & 0.1441 & 0.1389 & 0.1504 & 0.2074 & 0.1229 & 0.1244 & 0.1480 \\
\hline Mayor Oking & 0.2228 & 0.1580 & 0.1546 & 0.2131 & 0.3076 & 0.2996 & 0.2259 \\
\hline Cirimekar & 0.1504 & 0.1358 & 0.1493 & 0.0845 & 0.1219 & 0.1150 & 0.1262 \\
\hline Nanggewer & 0.1400 & 0.1645 & 0.1618 & 0.0952 & 0.1418 & 0.1338 & 0.1395 \\
\hline
\end{tabular}


Tabel Normalisasi Alternatif Terhadap Kriteria Nilai

\begin{tabular}{|c|c|c|c|c|c|c|c|}
\hline & Sukahati & Pabuaran & Pakansari & Mayor Oking & Cirimekar & Nanggewer & Rata / Vp \\
\hline Sukahati & 0.1593 & 0.1695 & 0.1558 & 0.1969 & 0.1095 & 0.1464 & 0.1562 \\
\hline Pabuaran & 0.1461 & 0.1555 & 0.1571 & 0.1937 & 0.1200 & 0.1379 & 0.1517 \\
\hline Pakansari & 0.1720 & 0.1666 & 0.1683 & 0.1955 & 0.1266 & 0.1544 & 0.1639 \\
\hline Mayor Oking & 0.1730 & 0.1716 & 0.1841 & 0.2139 & 0.3901 & 0.2560 & 0.2315 \\
\hline Cirimekar & 0.1755 & 0.1563 & 0.1604 & 0.0662 & 0.1207 & 0.1451 & 0.1374 \\
\hline Nanggewer & 0.1742 & 0.1805 & 0.1745 & 0.1338 & 0.1331 & 0.1601 & 0.1594 \\
\hline
\end{tabular}

Tabel Normalisasi Alternatif Terhadap Kriteria Ukuran

\begin{tabular}{|l|c|c|c|c|c|c|c|}
\hline & Sukahati & Pabuaran & Pakansari & Mayor Oking & Cirimekar & Nanggewer & Rata / Vp \\
\hline Sukahati & 0.1293 & 0.1583 & 0.1513 & 0.1023 & 0.1246 & 0.1225 & 0.1314 \\
\hline Pabuaran & 0.1303 & 0.1596 & 0.1634 & 0.1929 & 0.1204 & 0.1738 & 0.1567 \\
\hline Pakansari & 0.1396 & 0.1595 & 0.1633 & 0.1888 & 0.1329 & 0.1735 & 0.1596 \\
\hline Mayor Oking & 0.2634 & 0.1723 & 0.1802 & 0.2083 & 0.3394 & 0.1730 & 0.2228 \\
\hline Cirimekar & 0.1400 & 0.1786 & 0.1657 & 0.0827 & 0.1348 & 0.1703 & 0.1454 \\
\hline Nanggewer & 0.1973 & 0.1716 & 0.1760 & 0.2251 & 0.1479 & 0.1869 & 0.1841 \\
\hline
\end{tabular}

Tabel Normalisasi Alternatif Terhadap Kriteria Jarak

\begin{tabular}{|l|c|c|c|c|c|c|c|}
\hline & Sukahati & Pabuaran & Pakansari & $\begin{array}{c}\text { Mayor } \\
\text { Oking }\end{array}$ & Cirimekar & Nanggewer & Rata / Vp \\
\hline Sukahati & 0.1574 & 0.1493 & 0.1548 & 0.1654 & 0.1221 & 0.1545 & 0.1506 \\
\hline Pabuaran & 0.1530 & 0.1452 & 0.1551 & 0.1698 & 0.1214 & 0.1061 & 0.1418 \\
\hline Pakansari & 0.1683 & 0.1550 & 0.1656 & 0.1726 & 0.1300 & 0.1592 & 0.1584 \\
\hline Mayor Oking & 0.1798 & 0.1615 & 0.1813 & 0.1889 & 0.1162 & 0.3509 & 0.1964 \\
\hline Cirimekar & 0.1673 & 0.1552 & 0.1654 & 0.2112 & 0.1298 & 0.0584 & 0.1479 \\
\hline Nanggewer & 0.1742 & 0.2339 & 0.1779 & 0.0921 & 0.3804 & 0.1710 & 0.2049 \\
\hline
\end{tabular}

Tabel Nilai Random Indeks (RI)

\begin{tabular}{|c|c|c|c|c|c|c|c|c|c|c|}
\hline $\mathrm{N}$ & 1 & 2 & 3 & 4 & 5 & 6 & 7 & 8 & 9 & 10 \\
\hline $\mathrm{RI}$ & 0.00 & 0.00 & 0.52 & 0.9 & 1.11 & 1.24 & 1.35 & 1.40 & 1.45 & 1.49 \\
\hline
\end{tabular}

\section{Bobot Rasio dan Konsistensi Rasio Kriteria}

$$
\begin{aligned}
& \text { Responden X vek. Pref } \\
& \begin{array}{c}
\text { Rata / } \\
\text { Vp }
\end{array} \\
& \left|\begin{array}{llll}
1.0000 & 0.9751 & 1.5959 & 1.3040 \\
1.0255 & 1.0000 & 2.5418 & 1.6311 \\
0.6266 & 0.3934 & 1.0000 & 1.5060 \\
0.7669 & 0.6131 & 0.6640 & 1.0000
\end{array}\right| \mathrm{x} \\
& \mathrm{Vp} \\
& =\left|\begin{array}{l}
1.1607 \\
1.4168 \\
0.7780 \\
0.7369
\end{array}\right| \\
& \begin{array}{l}
0.2836 \\
0.3433 \\
0.1911 \\
0.1820
\end{array} \\
& =\begin{array}{r}
4.0931 \\
4.1268 \\
4.0713 \\
4.0478 \\
\hline 16.33901
\end{array} \\
& \lambda \text { maksimum } \\
& =4.084752 \\
& \text { Konsistensi Indeks } \\
& =0.0283 \\
& \text { Konsistensi Ratio } \\
& =0.0314
\end{aligned}
$$

Perhitungan diatas adalah nilai dasar yang ada pada Tabel Rekap Data Kriteria yang kemudian di kalikan dengan VP. Hasilnya (x) kemudian di bagi kembali dengan Ax (Vp) yang menghasilkan Lamda dari setiap kolomnya. Untuk menghitung $\lambda$ maksimum adalah menggunakan fungsi average dari jumlah total Lamda. Kemudian menentukan Konsistensi Indeks dengan Persamaan (1). Setelah di dapatkan nilai Konsistensi Indeks di bagi dengan nilai RI (Nilai Random Indeks) 
sehingga di hasilkanlah nilai Konsistensi Rasio (CR). Tahapan ini diulang kembali untuk menentukan Konsistensi Ratio dari alternatif terhadap setiap kriteria (Lokasi, Nilai Jual Lokasi, Ukuran Reklame, Jarak dengan Utilitas Umum)

Tabel Nilai Konsistensi Rasio Alternatif Terhadap Kriteria Lokasi

\begin{tabular}{|llllll}
1.0000 & 1.9846 & 1.5803 & 1.0221 & 1.5140 & 1.6265 \\
0.5039 & 1.0000 & 0.9719 & 0.8540 & 0.9936 & 0.8206 \\
0.6328 & 1.0289 & 1.0000 & 0.9734 & 1.0078 & 0.9300 \\
0.9784 & 1.1710 & 1.0273 & 1.0000 & 2.5226 & 2.2397 \\
0.6605 & 1.0064 & 0.9923 & 0.3964 & 1.0000 & 0.8596 \\
0.6148 & 1.2186 & 1.0753 & 0.4465 & 1.1633 & 1.0000
\end{tabular}$|\times| \begin{aligned} & 0.2256 \\
& 0.1348 \\
& 0.1480 \\
& 0.2259 \\
& 0.1262 \\
& 0.1395\end{aligned}|=| \begin{aligned} & 1.3759 \\
& 0.8251 \\
& 0.9063 \\
& 1.3872 \\
& 0.7672 \\
& 0.8493\end{aligned} \mid \begin{aligned} & 0.2256 \\
& 0.1348 \\
& 0.1480 \\
& 0.2259 \\
& 0.1262 \\
& 0.1395\end{aligned}$

Tabel Nilai Konsistensi Rasio Alternatif Terhadap Kriteria Nilai

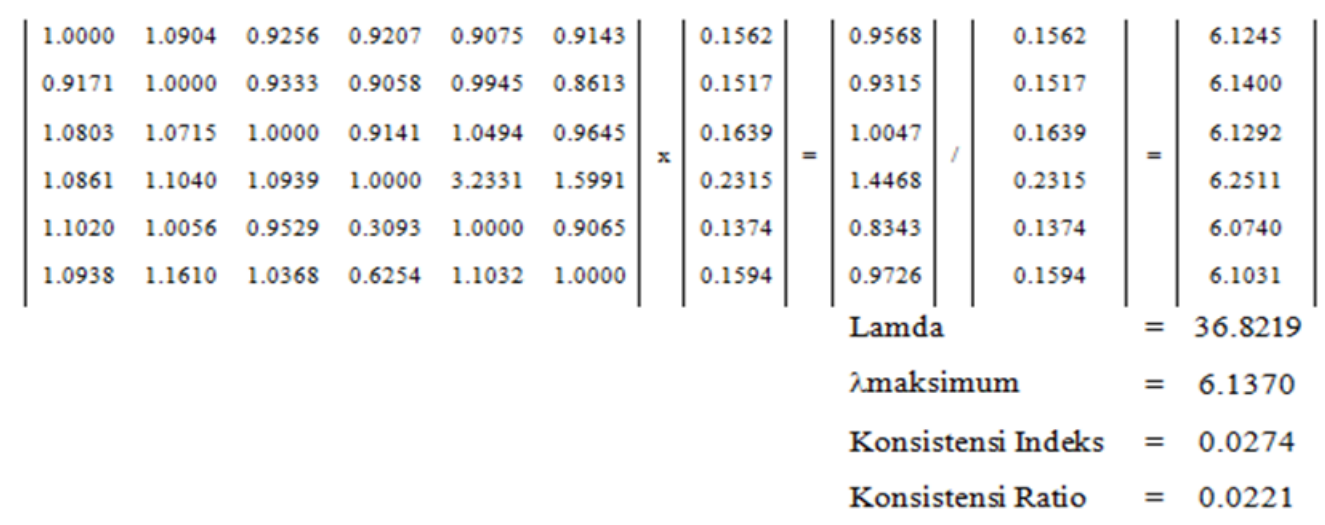

Tabel Nilai Konsistensi Rasio Alternatif Terhadap Kriteria Ukuran

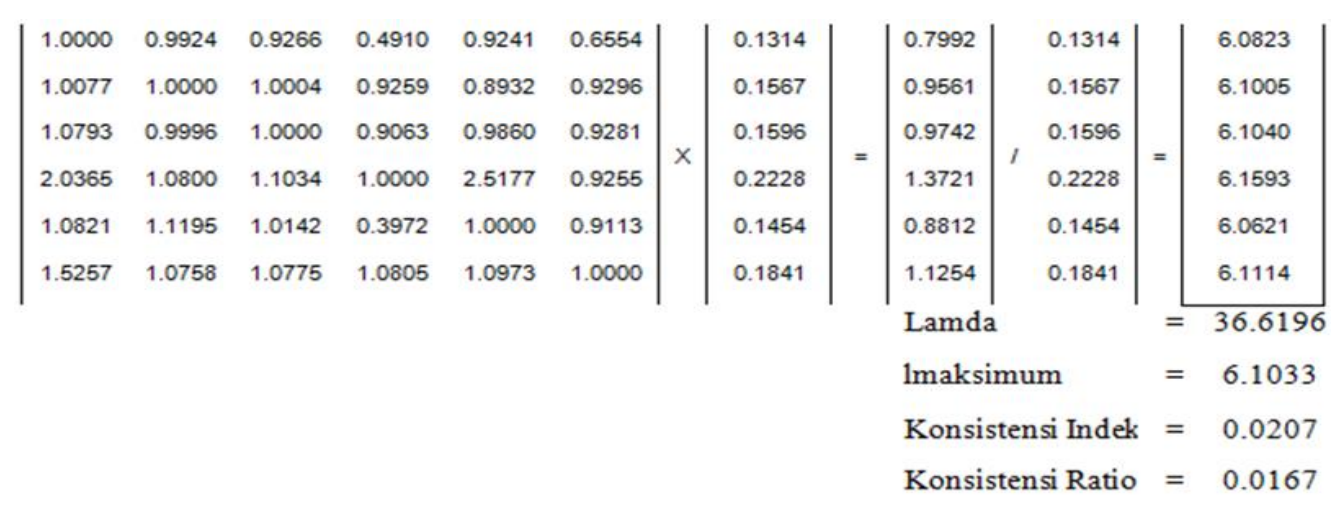

Tabel Nilai Konsistensi Rasio Alternatif Terhadap Kriteria Jarak

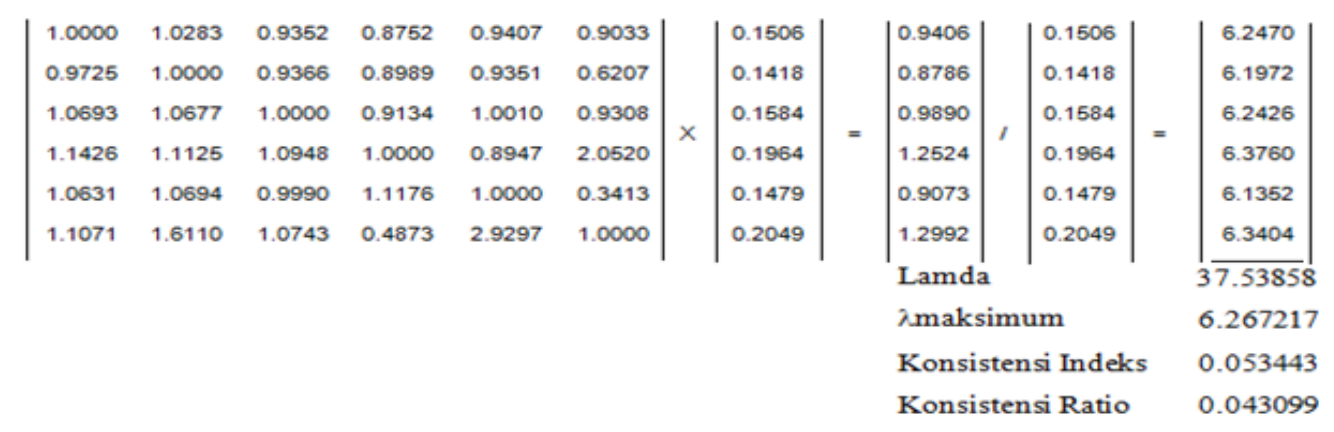


Bila hasil Konsistensi Rasio mempunyai nilai CR $<\mathbf{0 . 1 0 0}$ maka ketidak konsistenan pendapat dari pengambil keputusan dapat diterima atau data dianggap telah konsisten.

Dan apabila nilai tidak terpenuhi maka pengisian data quisioner atau penilaian harus di ulang. Namun karena kondisi konsistensi terpenuhi maka dilanjutkan dengan pembobotan triangular fuzzy number (TFN).

\section{d. Pembobotan Tringular Fuzzy Number (TFN)}

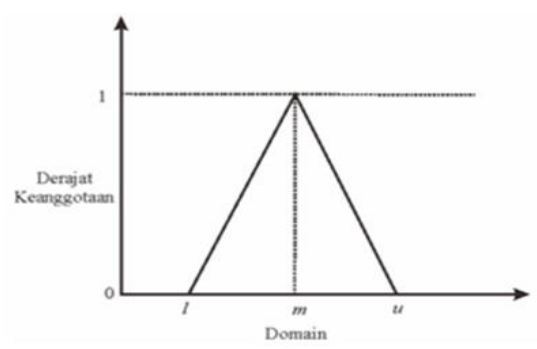

Gambar Fungsi Keanggotaan Segitiga

Chang mendefinisikan nilai intensitas AHP ke dalam skala fuzzy segitiga yaitu membagi tiap himpunan fuzzy dengan (2), kecuali untuk intensitas kepentingan satu (1). (Chang, 1996)

Tabel Skala triangular fuzzy number (TFN).

\begin{tabular}{ccc}
\hline $\begin{array}{c}\text { Skala } \\
\text { AHP }\end{array}$ & TFN & TFN Inverse \\
\hline 1 & $(1,1,1)$ & $(1,1,1)$ \\
\hline 2 & $(1 / 2,1,3 / 2)$ & $(2 / 3,1,2)$ \\
\hline 3 & $(1,3 / 2,2)$ & $(1 / 2,2 / 3,1)$ \\
\hline 4 & $(3 / 2,2,5 / 2)$ & $(2 / 5,1 / 2,2 / 3)$ \\
\hline 5 & $(2,5 / 2,3)$ & $(1 / 3,2 / 5,1 / 2)$ \\
\hline 6 & $(5 / 2,3,7 / 2)$ & $(2 / 7,1 / 3,2 / 5)$ \\
\hline 7 & $(3,7 / 2,4)$ & $(1 / 4,2 / 7,1 / 3)$ \\
\hline 8 & $(7 / 2,4,9 / 2)$ & $(2 / 9,1 / 4,2 / 7)$ \\
\hline 9 & $(4,9 / 2,9 / 2)$ & $(2 / 9,2 / 9,1 / 4)$ \\
\hline
\end{tabular}

Maka dari data nilai dasar kita yaitu Tabel Rekap Data Kriteria kedalam skala triangular fuzzy number (TFN) dan didapatkan nilai konversi pada tabel diatas, dilanjutkan proses konversi nilai ahp menjadi $t f n$ kemudian menjumlahkan keseluruhan tiap-tiap bilangan fuzzy pada baris dan kolom seperti pada tabel berikut:

Tabel Nilai Konversi TFN Kriteria

\begin{tabular}{|c|c|c|c|c|c|c|c|c|c|c|c|c|c|c|c|}
\hline & \multicolumn{3}{|c|}{ Lokasi } & \multicolumn{3}{|c|}{ Nilai } & \multicolumn{3}{|c|}{ Ukuran } & \multicolumn{3}{|c|}{ Jarak } & \multirow{2}{*}{1} & \multirow{2}{*}{$\mathbf{m}$} & \multirow{2}{*}{$\mathbf{u}$} \\
\hline & 1 & $\mathbf{m}$ & $\mathbf{u}$ & 1 & $\mathbf{m}$ & $\mathbf{u}$ & l & $\mathbf{m}$ & $\mathbf{u}$ & 1 & $\mathbf{m}$ & $\mathbf{u}$ & & & \\
\hline Lokasi & 1.00 & 1.00 & 1.00 & 1.00 & 1.00 & 1.00 & 0.50 & 1.00 & 1.50 & 1.00 & 1.00 & 1.00 & 3.50 & 4.00 & 4.50 \\
\hline Nilai & 1.00 & 1.00 & 1.00 & 1.00 & 1.00 & 1.00 & 1.00 & 1.50 & 2.00 & 0.50 & 1.00 & 1.50 & 3.50 & 4.50 & 5.50 \\
\hline Ukuran & 1.00 & 1.00 & 1.00 & 1.00 & 1.00 & 1.00 & 1.00 & 1.00 & 1.00 & 0.50 & 1.00 & 1.50 & 3.50 & 4.00 & 4.50 \\
\hline Jarak & 1.00 & 1.00 & 1.00 & 1.00 & 1.00 & 1.00 & 1.00 & 1.00 & 1.00 & 1.00 & 1.00 & 1.00 & 4.00 & 4.00 & 4.00 \\
\hline \multicolumn{13}{|c|}{ JUMLAH } & 14.50 & 16.50 & 18.50 \\
\hline
\end{tabular}

Setelah nilai jumlah baris dan kolom diperoleh, selanjutnya menghitung nilai fuzzy synthetic extent menggunakan persamaan fuzzy synthetic extent berikut ini : 


$$
\begin{aligned}
S_{i} & =\sum_{\substack{j=1 \\
\text { dengan }}}^{m} \boldsymbol{M}_{g_{i}}^{j} \otimes\left[\sum_{i=1}^{n} \sum_{j=1}^{m} M_{g_{i}}^{j}\right]^{-1} \\
\sum_{j=1}^{m} M_{g t}^{j} & =\left(\sum_{j=1}^{m} \iota_{j} \cdot \sum_{j=1}^{m} m_{j} \cdot \sum_{j=1}^{m} u_{j}\right)
\end{aligned}
$$

Sehingga diperoleh nilai $\left[\sum_{i=1}^{n} \sum_{j=1}^{m} M_{g_{i}}^{j}\right]^{-1}$ Adalah $\left(\frac{1}{18.50}, \frac{1}{16.50}, \frac{1}{14.50}\right)$

Selanjutnya menggunakan Persamaan fuzzy synthetic extent di hitung nilai fuzzy synthetic extent, diperoleh: $\quad$ Lokasi $=(3.50,4.00,4.50) \times\left(\frac{1}{18.50}, \frac{1}{16.50}, \frac{1}{14.50}\right)=0.1892,0.2424,0.3103$ Nilai $=(3.50,4.50,5.50) \times\left(\frac{1}{18.50}, \frac{1}{16.50}, \frac{1}{14.50}\right)=0.1892,0.2727,0.3793$ Ukuran $=(3.50,4.00,4.50) \times\left(\frac{1}{18.50}, \frac{1}{16.50}, \frac{1}{14.50}\right)=0.1892,0.2424,0.3103$ Jarak $=(4.00,4.00,4.00) \times\left(\frac{1}{18.50}, \frac{1}{16.50}, \frac{1}{14.50}\right)=0.2162,0.2424,0.2759$

\begin{tabular}{|c|c|c|c|c|}
\hline \multirow{2}{*}{ Kriteria } & \multicolumn{3}{|c|}{$\mathrm{Si}$} & \\
\hline & $\mathrm{L}$ & M & $\mathrm{U}$ & \\
\hline Lokasi & 0.1892 & 0.2424 & 0.3103 & \\
\hline Nilai & 0.1892 & 0.2727 & 0.3793 & \\
\hline Ukuran & 0.1892 & 0.2424 & 0.3103 & jika $l_{2} \geq u_{1}$ \\
\hline Jarak & 0.2162 & 0.2424 & 0.2759 & $\overline{\left.-l_{2}\right)}$, lainnya \\
\hline
\end{tabular}

Tabel Nilai Fuzzy Synthetic

Dari nilai fuzzy synthetic yang telah di hitung, maka selanjutnya dilakukan perbandingan tingkat kemungkinan dengan persamaan tingkat kemungkinan TFN sebagai berikut :

Akan menghasilkan persamaan tingkat kemungkinan seperti tabel dibawah ini, yang kemudian diambil nilai minimum dari setiap baris.

Tabel Persamaan tingkat kemungkinan

\begin{tabular}{|l|c|c|c|c|c|}
\hline & $\mathrm{S} 1 \geq$ & $\mathrm{S} 2 \geq$ & $\mathrm{S} 3 \geq$ & $\mathrm{S} 4 \geq$ & \\
\hline d' lokasi & 1.0000 & 1.0000 & 1.0000 & 1.0000 & \multirow{2}{*}{ total } \\
\cline { 1 - 5 } d' nilai & 0.7999 & 1.0000 & 0.7999 & 0.7999 & \\
\hline d' ukuran & 1.0000 & 1.0000 & 1.0000 & 1.0000 & \\
\hline d' jarak & 1.0000 & 1.0000 & 1.0000 & 1.0000 & \\
\cline { 1 - 5 } \multicolumn{1}{|c|}{ Min $=$} & 0.7999 & 1.0000 & 0.7999 & 0.7999 & 3.3998 \\
\hline
\end{tabular}

Setelah didapat hasil d' dari setiap kriteria, dan mendapatkan nilai minimumnya maka langkah selanjutnya vector bobot dinormalisasi dengan cara membagi nilai minimum dari setiap kriteria / alternatif, dengan jumlah seluruh nilai minimum kriteria atau alternatifnya. Maka diperoleh nilai sebagai berikut : 


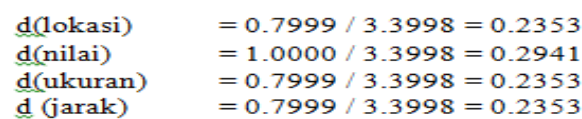

Dari data diatas diketahui vector bobot kriteria $(\mathrm{W})=0.2353,0.2941,0.2353,0.2353$

Langkah dan proses yang sama dilakukan pada setiap alternatif terhadap kriteria untuk memperoleh vector bobot. Hasil penghitungannya sebagai berikut:

Tabel Vector bobot alternatif terhadap Setiap Kriteria

\begin{tabular}{|c|c|c|c|c|}
\hline & LOKASI & NILAI & UKURAN & JARAK \\
\hline Sukahati & 0.1810 & 0.1512 & 0.1535 & 0.1535 \\
\hline Pabuaran & 0.1533 & 0.1512 & 0.1535 & 0.1535 \\
\hline Pakansari & 0.1533 & 0.1512 & 0.1535 & 0.1535 \\
\hline Mayor Oking & 0.2059 & 0.2439 & 0.2323 & 0.1535 \\
\hline Cirimekar & 0.1533 & 0.1512 & 0.1535 & 0.1535 \\
\hline Nanggewer & 0.1533 & 0.1512 & 0.1535 & 0.2323 \\
\hline
\end{tabular}

Selanjutnya hasil vector bobot alternatif terhadap setiap kriteria diatas di kalikan dengan vector bobot kriteria $\mathrm{W}$ (kriteria) yang hasil akhirnya akan keluar sebagai nilai perangkingan Titik Strategis Pemasangan Reklame Rokok di Kecamatan Cibinong Kabupaten Bogor berdasarkan 4 Kriteria dan 6 Alternatif yang ada.

Tabel Perkalian Bobot Alternatif Terhadap Kriteria

\begin{tabular}{|c|c|c|c|c|c|c|c|c|}
\hline Altematif & LOKASI & NILAI & UKURAN & JARAK & & KRITERIA & & Hasil \\
\hline Sukahati & 0.1810 & 0.1512 & 0.1535 & 0.1535 & \multirow{6}{*}{$\mathrm{x}$} & & \multirow{6}{*}{$=$} & 0.1593 \\
\hline Pabuaran & 0.1533 & 0.1512 & 0.1535 & 0.1535 & & 0.2353 & & 0.1528 \\
\hline Pakansari & 0.1533 & 0.1512 & 0.1535 & 0.1535 & & 0.2941 & & 0.1528 \\
\hline Mayor Oking & 0.2059 & 0.2439 & 0.2323 & 0.1535 & & 0.2353 & & 0.2110 \\
\hline Cirimekar & 0.1533 & 0.1512 & 0.1535 & 0.1535 & & 0.2353 & & 0.1528 \\
\hline Nanggewer & 0.1533 & 0.1512 & 0.1535 & 0.2323 & & & & 0.1713 \\
\hline
\end{tabular}

Dari nilai pada tabel diatas dapat dilihat hasil Rangking Titik Strategis Pemasangan Reklame Produk Rokok di Kecamatan Cibinong Kabupaten Bogor.

\begin{tabular}{|c|c|c|}
\hline Ranking & Alternatif & Bobot Akhir \\
\hline 1 & Mayor Oking & 0.2110 \\
\hline 2 & Nanggewer & 0.1713 \\
\hline 3 & Sukahati & 0.1593 \\
\hline 4 & Pabuaran & 0.1528 \\
\hline 5 & Pakansari & 0.1528 \\
\hline 6 & Cirimekar & 0.1528 \\
\hline & tatal & 1.0000 \\
\hline
\end{tabular}

\section{KESIMPULAN DAN SARAN}

\section{A. Kesimpulan}


Berdasarkan permasalahan untuk menentukan bobot indikator-indikator pada Penentuan Titik Strategis Pemasangan Reklame Rokok di Kecamatan Cibinong Kabupaten Bogor. Dari penelitian yang dilakukan, maka dapat disimpulkan sebagai berikut :

1. Bobot Kriteria terpenting adalah Nilai Jual Lokasi dan Jarak dengan Utilitas umum

2. Dari hasil perhitungan kriteria dan alternatif menggunakan metode FAHP, diperoleh hasil Mayor Oking menjadi titik strategis dengan nilai tertinggi 0.2110 dan menjadi titik strategis terbaik untuk pemasangan reklame produk rokok di Kecamatan Cibinong Kabupaten Bogor.

\section{A. Saran}

Untuk meningkatkan hasil penelitian pada waktu yang akan datang, saran-saran dibawah ini dapat dijadikan sebagai masukan positif, sebagai berikut :

1. Penelitian menggunakan metode FAHP dapat dikembangkan dengan menggabungkan dengan metode-metode lain yang bersinergi, sehingga diharapkan akan memperoleh hasil yang lebih efisien dan efektif.

2. Pembuatan / pengembangan sistem atau aplikasi dengan menerapkan FAHP sehingga memudahkan untuk menentukan Titik Strategis Pemasangan Reklame Produk Rokok di Kecamatan Cibinong dan Kecamatan lainnya yang berada di Kabupaten Bogor.

\section{Daftar Pustaka}

Alwi, Sumpeno Surya dan Purnama Eddy Ketut I Jurusan Teknik Elektro Institut Teknologi Sepuluh November yang mengangkat judul Sistem Pendukung Keputusan Pemilihan Guru Berprestasi Menggunakan Metode Fuzzy Analythical Hierarchi Process

Aprianto Hadi Joko,Gandhiadi G.K.,Nilakusumawati Eka Putu Desak pada Jurusan Matematika FMIPA Universitas Udayana yang mengangkat judul Pemilihan Kriteria Dalam Pembuatan Kartu Kredit dengan Menggunakan Metode Fuzzy Analythical Hierarchi Process.

Galus Eka Putra Muhammad, Sallu Sulfikar Nikentari Nerfita yang berjudul Analisa Penggunaan Metode AHP dan Fuzzy AHP Pada Perangkingan Siswa.

Kusrini, (2007). Konsep dan Aplikasi Sistem Pendukung Keputusan. Yogyakarta : Andi.

Kusumadewi,Sri.2013.Aplikasi Logika Fuzzy Aplikasi Untuk Pendukung Keputusan.Yogyakarta :

Graha Ilmu

Martono Nanang, Statistik Sosial Teori dan Aplikasi Program SPSS.

Permana Adi Sapta,Widjajanto Budi pada Fakultas Ilmu Komputer Universitas Dian Nuswantoro Semarang yang berjudul Sistem Pendukung Keputusan Berbasis Fuzzy Analytical Hierarchi Process untuk kelayakan Kredit Rumah.

Rahardjo Jani dan Sutapa Nyoman I yang merupakan Dosen Fakultas Teknologi Industri, Jurusan Teknik Industri Universitas Kristen Petra yang mengangkat judul Aplikasi Fuzzy Analythical Hierarchi Process dalam Seleksi Karyawan 
Jurnal IImiah Teknologi - Informasi dan Sains (TeknolS)

Volume 8 Nomor 1 Bulan Mei 2018 Hal. 29-47

p-ISSN : 2087-3891 dan e-ISSN : 2597-8918

Setiawan, Pujiastutik Reny (2015) pada Manajemen Informatika Universitas Trunojoyo madura yang berjudul Penerapan Metode Fuzzy Analytical Hierarchi Process untuk Pemilihan Supplier Batik Madura.

Sugiyono.2013.Metode Penelitian Kuantitatif Kualitatif dan R \& D. Bandung : Alfa Beta 